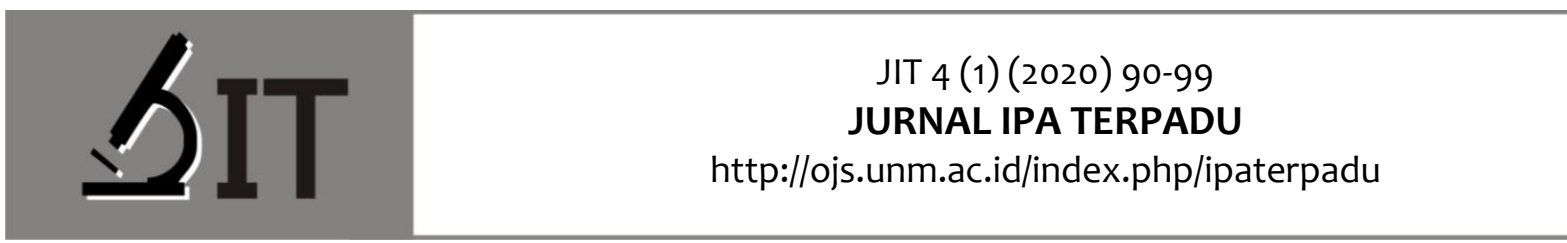

p-ISSN : 2597-8977

e-ISSN : 2597-8985

Nur Ngazizah *)

Universitas Muhammadiyah

Purworejo

Rizky Fadjar Choirrul

Linda

Universitas Muhammadiyah

Purworejo

Siska Giyan Kurniasari

Universitas Muhammadiyah

Purworejo

Aulia Fakhrina

Universitas Muhammadiyah

Purworejo

Widanti

Universitas Muhammadiyah

Purworejo

*) Correspondence Author: ngazizah@umpwr.ac.id

\section{ANALISIS KEMAMPUAN HOTS MELALUI PJBL DIMASA PANDEMI COVID-19 MAHASISWA SEMESTER 2 PADA MATA KULIAH IPA LANJUT}

Abstrak: PJBL merupakan model pembelajaran yang efektif dilakukan ketika pandemi covid-19 untuk meningkatkan HOTS. Penelitian ini bertujuan untuk mendeskripsikan kemampuan HOTS mahasiswa dalam menyelesaikan resume, peta konsep, komentar, dan UAS materi gelombang dan bunyi setelah diberikan pembelajaran dengan model PJBL. Metode penelitian yang digunakan adalah deskriptif dengan pendekatan kuantitatif. Subjek penelitian yaitu mahasiswa semester2 program studi PGSD yang berjumlah 91 orang. Teknik pengumpulan data dengan membuat resume untuk (berpikir kritis), peta konsep (berpikir kritis), komentar (keputusan), dan UAS (memecahkan masalah). Berdasarkan hasil analisis data, diketahui bahwa kemampuan berpikir tingkat tinggi mahasiswa dalam pembelajaran gelombang dan bunyi sebagai berikut: (1) Persentase HOTS proyek resume dengan kategori sangat baik adalah 31,86\%, kategori baik 58,24\%, kategori cukup 2,10\%, kategori kurang 5,25\%, dan kategori sangat kurang 2,10\%; (2) Presentase HOTS proyek peta konsep kategori sangat baik adalah $17,58 \%$, kategori baik $71,42 \%$, kategori cukup 5,50\%, kategori kurang 4,40\%, dan kategori sangat kurang 1,10\%; (3) Presentase HOTS proyek komentar dengan kategori sangat baik adalah 20,87\%, kategori baik 69,24\%, kategori cukup $4,40 \%$, kategori kurang 2,10\%, dan kategori sangat kurang 3,30\%; (4) Presentase HOTS proyek UAS dengan kategori sangat baik adalah $0 \%$, kategori baik 96,70\%, kategori cukup 3,29\%, kategori kurang $0 \%$ dan kategori sangat kurang $0 \%$.

Kata Kunci: gelombang dan bunyi, HOTS, PJBL

Abstract: PJBL is a learning model that is effective during the Covid-19 pandemic to increase HOTS. This study aims to describe students' HOTS abilities in completing resumes, concept maps, comments, and sound wave and sound final exam material after being given learning using the PJBL model. The research method used is descriptive with a quantitative approach. The research subjects were 91 semester students of the PGSD study program. Data collection techniques by making a resume for (critical thinking), concept maps (critical thinking), comments (decisions), and UAS (solving problems). Based on the results of data analysis, it is known that the high order thinking skills of students in learning waves and sound are as follows: (1) The percentage of HOTS resume projects with very good categories is $31.86 \%$, good categories are $58.24 \%$, enough categories are $2.10 \%$, the poor category is $5.25 \%$, and the very poor category is $2.10 \%$; (2) The percentage of HOTS concept map project with very good category was $17.58 \%$, good category $71.42 \%$, moderate category $5.50 \%$, poor category $4.40 \%$, and very poor category $1.10 \%$; (3) The HOTS percentage of comment projects with very good category was $20.87 \%$, good category $69.24 \%$, enough category $4.40 \%$, less category $2.10 \%$, and 
Nur Ngazizah, Rizky Fadjar Choirrul Linda, Siska Giyan Kurniasari, Aulia Fakhrina, Widanti / JIT Vol 4.

No 1.2020

ISSN 2597-8977

very poor category $3.30 \%$; (4) The percentage of HOTS on UAS project with very good category was $0 \%$, good category $96.70 \%$, enough category $3.29 \%$, less category $0 \%$ and very poor category $0 \%$.

Keyword: Waves and sounds,HOTS , PJBL 


\section{PENDAHULUAN}

Ilmu pengetahuan alam atau yang biasa disebut dengan IPA merupakan salah satu cabang keilmuan yang mempelajari diri sendiri, alam sekitar dan mengaplikasikannya dalam kehidupan sehari- hari, salah satunya materi gelombang dan bunyi yang dipelajari oleh mahasiswa semester 2 Pendidikan Guru Sekolah Dasar Universitas Muhammadiyah Purworejo. Materi gelombang merupakan materi yang abstrak (Serway \& Jewett, dalam La Jumadin, et all., 2017: 325). Misalnya ketika mendemontrasikan gelombang yang merambat pada tali, gelombang tidak akan terlihat tanpa tali, sebab gelombang memerlukan suatu medium untuk dapat berpindah dari satu tempat ke tempat lain. Karakteristik dari konsep gelombang dan bunyi masih bersifat abstrak, sehingga memerlukan suatu kemampuan pada level yang lebih tinggi untuk dapat menguasainya. Kemampuan tersebut adalah kemampuan berpikir tingkat tinggi atau High Order Thingking Skills (HOTS).

High order thingking skills merupakan kemampuan untuk berpikir pada level yang lebih tinggi dengan melibatkan aktifitas mental seperti menganalisis, mengevaluasi, dan mencipta pengetahuan baru guna menentukan suatu keputusan dan memecahkan masalah. High order thingking skills akhir-akhir ini sering sekali dikaitkan dengan pembelajaran abad 21, karena dianggap sebagai kompetensi yang relevan dengan keadaan yang kompetitif seperti saat ini. High order thingking skills membekali diri dengan kemampuan berpikir kreatif (creative thinking), kemampuan berpikir kritis (critical thinking), kemampuan membuat keputusan (decision making), dan kemampuan memecahkan masalah (problem solving). Pada mata kuliah ini mahasiswa diminta mengerjakan resume untuk meningkatkan kemampuan berpikir kritis, peta konsep untuk meningkatkan kemampuan berpikir kreatif, ujian akhir semester untuk meningkatkan kemampuan memecahkan masalah, dan komentar dari pertanyaan untuk meningkatkan kemampuan membuat keputusan.

Pembiasaan yang dilakukan mahasiswa dalam mengerjakan proyek yang ada bukan sekedar menghafal dan menyatakan kembali informasi yang diketahui namun juga menghubungkan, memanipulasi, dan mentransformasi pengetahuan serta pengalaman yang telah dimiliki. Kemampuan berpikir tingkat tinggi memiliki peran yang cukup penting dalam proses pengajaran dan pembelajaran. Apabila tingkat berpikir siswa naik pada level yang lebih tinggi juga akan berdampak positif bagi pendidikan di Indonesia. Mahasiswa sebagai akademisi yang seharusnya memiliki intelektual yang baik sudah selayaknya terus memperbaiki diri dalam mengembangkan kemampuan kognitifnya. Maka untuk mengembangkan kemampuan tersebut diperlukan suatu model pembelajaran yang dapat meningkatkan kreativitas dalam menemukan gagasan baru ataupun suatu karya untuk mendapatkan jawaban dari sebuah pertanyaan dengan pembelajaran berbasis proyek. Siswa dalam pembelajaran berbasis proyek dapat menentukan sendiri proses pembelajarannya secara kolaboratif, melakukan penelitian dan membuat proyekproyek kreatif yang merefleksikan pengetahuan yang mereka miliki (Finita Dwi, 2015: 1). Stearns (dalam Finita Dwi, 2015: 1) menyatakan bahwa melalui PJBL siswa mengalami peningkatan dalam menginternalisasi konsep dan keterampilan yang berhubungan dengan mata pelajaran sains, serta memiliki kecenderungan untuk mengingat dan memahami berbagai informasi yang didapatkan melalui pelaksanaan PJBL.

Hasil penelitian yang dilakukan oleh Riska Niswara et all., 2019: 86) menyebutkan bahwa penerapan model pembelajaran berbasis proyek (PJBL) dapat meningkatkan kemampuan HOTS siswa, namun dalam proses pembelajarannya dilakukan secara tatap muka langsung. Pada penelitian ini, pembelajaran berbasis proyek yang diterima mahasiswa tidak bertatap muka secara langsung seperti biasanya, melainkan harus menggunakan pembelajaran berbasis online diakibatkan pandemic covid-19 yang saat ini menerpa Indonesia bahkan seluruh dunia. Pembelajaran berbasis online apabila disinergikan dengan pembelajaran berbasis proyek akan memberikan dampak yang baik bagi mahasiswa. Hasil penelitian Chasanah et all., (2014: 22) yang 
menemukan, bahwa pembelajaran dengan model pembelajaran berbasis proyek lebih efektif daripada model pembelajaran konvensional dalam meningkatkan hasil belajar berupa kemampuan berpikir kreatif dan keterampilan proses sains siswa. Selaras dengan hal itu Kurniawan Arizona et all., (2020: 68) dalam penelitiannya mengatakan bahwa pembelajaran online berbasis proyek peserta didik dapat melalui pembelajaran yang bermakna sehingga pengetahuan dan ilmu yang didapatkan memiliki arti yang dapat dimanfaatkan sebagai bekal mereka menjadi problem solver dari permasalahan yang dihadapi.

Penelitian ini bertujuan untuk mendeskripsikan kemampuan high order thinking skills atau kemampuan berpikir tingkat tinggi mahasiswa semester 2 Pendidikan Guru Sekolah Dasar Universitas Muhammadiyah Purworejo dalam perkuliahan IPA lanjut setelah diberikan pembelajaran berbasis proyek dalam masa pandemic covid-19.

\section{METODE}

Metode penelitian ini adalah metode deskriptif dengan pendekatan kuantitatif. Sugiyono (2012: 15) mengemukakan bahwa metode penelitian deskriptif adalah metode yang digunakan untuk menggambarkan atau menganalisis suatu hasil penelitian tetapi tidak digunakan untuk membuat kesimpulan yang lebih luas. Metode penelitian deskriptif digunakan karena dalam penelitian ini akan mendeskripsikan kemampuan berpikir tingkat tinggi mahasiswa dalam menyelesaikan soal materi gelombang dan bunyi setelah diterapkan pembelajaran melalui model pembelajaran berbasis proyek. Subjek dalam penelitian ini adalah seluruh mahasiswa semester 2 pendidikan guru sekolah dasar Univeritas Muhammadiyah Purworejo yang mengambil mata kuliah IPA lanjut yang berjumlah 91 orang.

Teknik yang digunakan dalam pengambilan data yaitu teknik pengukuran. Alat ukur yang digunakan berupa instrumen tes untuk mengetahui kemampuan kognitif mahasiswa dalam menerapkan kemampuan HOTS secara tertulis yang terdiri dari keterampilan berfikir kreatif, kritis, memecahkan masalah, serta menganalisis. Tes yang digunakan dalam pengambilan data terlebih dahulu diuji validitas dan reliabilitas tes. Berdasarkan analisis uji coba soal diketahui bahwa soal dinyatakan valid dan reliabel. Adapun rincian instrumen tes disajikan pada Tabel 1.

Tabel. 1. Sebaran tes kemampuan berpikir tingkat tinggi

\begin{tabular}{cll}
\hline No & Tingkat Berpikir & \multicolumn{1}{c}{ Aspek } \\
\hline 1 & Creatif Thinking & Berpikir secara kreatif \\
& & Mengembangkan \\
& Mengimplementasi inovasi \\
& Critical Thinking & Memeriksa \\
& Mengkritik \\
& Problem Solving & Penalaran efektif \\
& & Menggunakan sistem berfikir \\
& & Membuat penilaian dan keputusan \\
& & Memecahkan masalah \\
& Menganalisis & Membedakan \\
& & Mengorganisasi \\
& & Menghubungkan \\
\hline
\end{tabular}

Data skor jawaban mahasiswa dalam menyelesaikan soal higher order thinking Skills (HOTS) akan dianalisis menggunakan statistik deskriptif. Adapun langkah-langkah analisis yaitu 1) mengubah skor menjadi nilai; 2) dan mengkategorikan nilai kemampuan berpikir tingkat tinggi mahasiswa yang mengacu pada International Center for the Assesment of Higher Order Thinking 
(Prasetyani et all., 2016). Tabel 2 (Kategori Kemampuan Berpikir Tingkat Tinggi Mahasiswa) membuat presentase kemampuan berpikir tingkat tinggi yang meliputi 4 aspek.

Tabel 2. Kategori Kemampuan Berpikir Tingkat Tinggi Mahasiswa

\begin{tabular}{cc}
\hline Nilai & Kategori \\
\hline $81-90$ & Sangat Baik \\
$61-80$ & Baik \\
$41-60$ & Cukup \\
$21-40$ & Kurang \\
$0-20$ & Sangat Kurang \\
\hline
\end{tabular}

Presentase kemampuan berpikir tingkat tinggi mahasiswa dalam menyelesaikan peta konsep untuk meningkatkan kemampuan berpikir kreatif (creative thinking), mengerjakan resume untuk meningkatkan kemampuan berpikir kritis (critical thinking), komentar untuk meningkatkan kemampuan membuat keputusan (decision making), dan ujian akhir semester untuk meningkatkan kemampuan memecahkan masalah (problem solving) pada materi gelombang dan bunyi setelah diberikan pembelajaran dengan model pembelajaran berbasis proyek menggunakan instrument tes dengan menilai lembar kerja mahasiswa yang dikerjakan mahasiswa ketika melakukan pembelajaran berbasis proyek. Dapat dihitung presentasenya dengan persamaan berikut.

$$
N P=\frac{R}{S M} \mathrm{X} 100
$$

Keterangan:

$\mathrm{NP} \quad=$ nilai presentase dicari

$\mathrm{R} \quad=$ skor mentah yang diperoleh

$\mathrm{SM}=$ skor maksimum ideal

\section{HASIL DAN PEMBAHASAN}

\section{Hasil}

Pembelajaran dilaksanakan sesuai langkah-langkah model pembelajaran berbasis proyek yaitu, diantaranya 1) penentuan pertanyaan mendasar dengan memberikan brainstorming sebagai pemicu awal berpikir mahasiswa, 2) menyusun perencanaan proyek berisi aturan main dalam menjalankan aktivitas tugas, 3) memberi proyek harian kepada peserta didik berupa laporan hasil, 4) monitoring, menguji hasil, dan 6) evaluasi pengalaman. Dikarenakan pandemi covid-19, pembelajaran dilakukan secara online menggunakan platform google classroom. Selama proses pembelajaran berlangsung, dosen hanya berperan sebagai fasilitator sehingga pembelajaran lebih terfokus pada mahasiswa. 
Tabel. 2 persentase kemampuan berpikir tingkat tinggi mahasiswa dalam menyelesaikan soal materi gelombang dan bunyi berdasarkan nilai aspek creatif thinking

\begin{tabular}{|c|c|c|c|}
\hline Nilai & Kategori & Frekuensi & Presentase (\%) \\
\hline $81-90$ & Sangat Baik & 16 & $17,58 \%$ \\
\hline $61-80$ & Baik & 65 & $71,42 \%$ \\
\hline $41-60$ & Cukup & 5 & $5,50 \%$ \\
\hline $21-40$ & Kurang & 4 & $4,40 \%$ \\
\hline $0-20$ & Sangat Kurang & 1 & $1,10 \%$ \\
\hline \multicolumn{2}{|c|}{ Jumlah } & 91 & 100,00 \\
\hline
\end{tabular}

Berdasarkan tabel 2 diketahui bahwa kategori sangat baik yang diperoleh mahasiswa dalam menyelesaikan peta konsep untuk meningkatkan kemampuan berpikir kreatif (creative thinking), yaitu 16 orang dengan prsentase $17,58 \%$, kategori baik diperoleh 57 orang dengan presentase $62,63 \%$. Kategori cukup diperoleh 8 orang dengan presentase $8,79 \%$, sedangkan kategori sangat kurang diperoleh 10 orang dengan presentase $10,98 \%$.

Tabel. 3 persentase kemampuan berpikir tingkat tinggi mahasiswa dalam menyelesaikan soal materi gelombang dan bunyi berdasarkan nilai aspek critical thinking

\begin{tabular}{cccc}
\hline Nilai & Kategori & Frekuensi & Presentase (\%) \\
\hline $81-90$ & Sangat Baik & 19 & $20,87 \%$ \\
$61-80$ & Baik & 63 & $69,24 \%$ \\
$41-60$ & Cukup & 4 & $4,40 \%$ \\
$21-40$ & Kurang & 2 & $2,10 \%$ \\
$0-20$ & Sangat Kurang & 3 & $3,30 \%$ \\
\hline \multicolumn{2}{c}{ Jumlah } & 91 & 100,00 \\
\hline
\end{tabular}

Berdasarkan tabel 3 diketahui bahwa kategori sangat baik yang diperoleh mahasiswa dalam menyelesaikan resume untuk meningkatkan kemampuan berpikir kreatif (critical thinking), yaitu 19 orang dengan prsentase $20,87 \%$, kategori baik diperoleh 62 orang dengan presentase $61,13 \%$. Kategori cukup diperoleh 1 orang dengan presentase 10, $98 \%$,sedangkan kategori sangat kurang diperoleh 9 orang dengan presentase $9,89 \%$.

Tabel. 4 persentase kemampuan berpikir tingkat tinggi mahasiswa dalam menyelesaikan soal materi gelombang dan bunyi berdasarkan nilai aspek problem solving.

\begin{tabular}{cccc}
\hline Nilai & Kategori & Frekuensi & Presentase (\%) \\
\hline $81-90$ & Sangat Baik & 0 & $0 \%$ \\
$61-80$ & Baik & 88 & $96,70 \%$ \\
$41-60$ & Cukup & 3 & $3,29 \%$ \\
$21-40$ & Kurang & 0 & $0 \%$ \\
$0-20$ & Sangat Kurang & 0 & $0 \%$ \\
\hline \multicolumn{2}{c}{ Jumlah } & 91 & 100,00 \\
\hline
\end{tabular}

Berdasarkan tabel 4 diketahui bahwa tidak ada mahasiswa yang mendapatkan nilai dalam kategori sangat baik dan baik dalam menyelesaikan ujian akhir semester untuk meningkatkan kemampuan berpikir kreatif (problem solving), dalam kategori cukup terdapat 88 mahasiswa dengan presentase $96,70 \%$. Sedangkan dalam kategori sangat kurang diperoleh 3 orang dengan presentase $3,29 \%$. 
Tabel. 5 persentase kemampuan berpikir tingkat tinggi mahasiswa dalam menyelesaikan soal materi gelombang dan bunyi berdasarkan nilai aspek decision making.

\begin{tabular}{cccc}
\hline Nilai & Kategori & Frekuensi & Presentase (\%) \\
\hline $81-90$ & Sangat Baik & 29 & $31,86 \%$ \\
$61-80$ & Baik & 53 & $58,24 \%$ \\
$41-60$ & Cukup & 2 & $2,10 \%$ \\
$21-40$ & Kurang & 5 & $5,52 \%$ \\
$0-20$ & Sangat Kurang & 2 & $2,10 \%$ \\
\hline \multicolumn{2}{c}{ Jumlah } & 91 & 100,00 \\
\hline
\end{tabular}

Berdasarkan tabel 5 diketahui bahwa kategori sangat baik yang diperoleh mahasiswa dalam menjawab komentar untuk meningkatkan kemampuan berpikir kreatif (decision making), yaitu 29 orang dengan prsentase 31, 86\%, kategori baik diperoleh 47 orang dengan presentase 51, $64 \%$. Kategori cukup diperoleh 6 orang dengan presentase 6,59\%, sedangkan kategori sangat kurang diperoleh 9 orang dengan presentase $9,89 \%$.

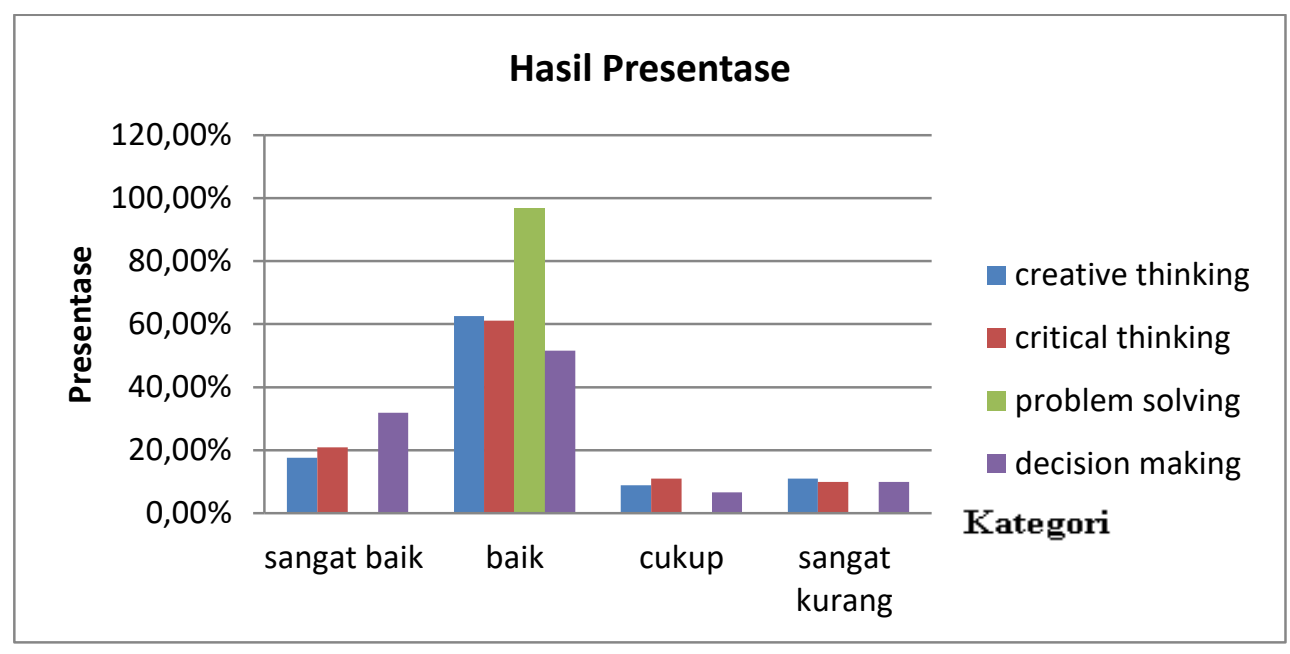

Gambar 1. Hasil presentase

\section{Pembahasan}

Meninjau hasil presentase dari keempat tabel di atas bahwa kemampuan berpikir tingkat tinggi mahasiswa dalam aspek creative thinking, critical thinking, problem solving dan decision making termasuk dalam kategori baik, hal itu terlihat ketika proses pembelajaran berlangsung mahasiswa secara aktif menjawab pertanyaan dan juga terbukti dari hasil pengerjaan proyek yang diberikan. Berdasarkan hasil analisis proyek membuat peta konsep, terlihat bahwa mahasiswa secara kreatif dapat mengembangkan dan mengimplementasikan ide-ide sesuai dengan materi yang telah diberikan. Menurut Sih Kusumaningrum dan D. Djukri (2016 : 242) dalam hasil penelitiannya dijelaskan bahwa model pembelajaran berbasis proyek dapat menjembantani siswa untuk dapat mengembangkan kreativitas melalui kegiatan berbasis proyek. Pada analisis proyek resume yang telah dikerjakan, mahasiswa secara mandiri mampu mengkonstruksi ide-ide yang telah didapat sehingga menghasilkan suatu karya sesuai yang diinginkan, hal ini selaras dengan hasil penelitian Dewi Insyasiska et all., (2015: 11) yang menyatakan bahwa pembelajaran berbasis proyek dapat melibatkan siswa secara mandiri dengan kriteria bahwa dalam pembelajaran tersebut akan meningkatkan daya pikir siswa menuju metakognitif seperti berpikir kritis terhadap proyek yang akan dikerjakan melalui permasalahan yang ditemukan oleh siswa. Sedangkan hasil 
analisis menjawab komentar, mahasiswa mampu membuat keputusan berdasarkan alternative jawaban dari modul yang telah dipelajari. Menurut Jonathan Hutapea dan Syarief Saadillah Lubis (2017: 300) pengambilan keputusan dalam pembelajaran berbasis proyek terjadi atau digunakan dalam semua aspek, pengambilan keputusan digunakan terlebih dahulu untuk menetapkan tujuan yang akan dicapai, kemudian diikuti dengan pengumpulan informasi yang teliti sehingga memberikan pilihan bervariasi dan di evaluasi secara sistematis untuk mengambil sebuah pilihan yang memenuhi tujuan yang telah ditetapkan sebelumnya. Aspek problem solving menunjukkan hasil presentase yang paling baik dibanding aspek HOTS lainnya, walaupun aspek lainnya samasama berada pada kategori baik. Pada aspek ini sebanyak 88 dari 91 mahasiswa masuk dalam kategori baik , sisanya hanya 3 mahasiswa yang masuk dalam kategori cukup.

Untuk aspek problem solving digunakan ujian akhir semester sebagai cara untuk mengetahui seberapa kemampuan berpikir krtisis mahasiswa. Hasil ujian akhir semester menunjukkan mahasiwa mampu memecahkan masalah mengenai soal-soal yang diberikan dengan mengkontruksi pemikirannya untuk mencari penyelesaian masalah. Hal tersebut terjadi karena mahasiswa dibiasakan untuk mengungkapkan masalah dengan melakukan kegiatan pembelajaran yang sesuai dengan kehidupan konkret mereka. Faktor-faktor tersebut diperkuat dengan enam aspek yang dapat digunakan untuk mengukur sejauh mana keterampilan pemecahan masalah peserta didik menurut Mourtos, Okamoto dan Rhee dalam Yoki ariana et all., (2018: 13) sebagai berikut: (1) menentukan masalah, dengan mendefinisikan masalah, menjelaskan permasalahan, menentukan kebutuhan data dan informasi yang harus diketahui sebelum digunakan untuk mendefinisikan masalah sehingga menjadi lebih detail, dan mempersiapkan kriteria untuk menentukan hasil pembahasan dari masalah yang dihadapi, (2) mengeksplorasi masalah, dengan menentukan objek yang berhubungan dengan masalah, memeriksa masalah yang terkait dengan asumsi dan menyatakan hipotesis yang terkait dengan masalah, (3) merencanakan solusi dimana peserta didik mengembangkan rencana untuk memecahkan masalah, memetakan sub-materi yang terkait dengan masalah, memilih teori prinsip dan pendekatan yang sesuai dengan masalah, dan menentukan informasi untuk menemukan solusi, (4) melaksanakan rencana, pada tahap ini peserta didik menerapkan rencana yang telah ditetapkan, (5) memeriksa solusi, mengevaluasi solusi yang digunakan untuk memecahkan masalah, (6) mengevaluasi, dalam langkah ini, solusi diperiksa, asumsi yang terkait dengan solusi dibuat, memperkirakan hasil yang diperoleh ketika mengimplementasikan solusi dan mengkomunikasikan solusi yang telah dibuat.

Berdasarkan temuan penelitian yang dilakukan, dapat diketahui bahwa, model pembelajaran berbasis proyek yang digunakan sudah mampu meningkatkan kemampuan berpikir tingkat tinggi mahasiswa terutama untuk asepek problem solving. Hal ini disebabkan bahwa jenis penugasan yang diberikan dalam mengerjakan soal tes lebih sederhana dibanding proyek lainnya, dan faktor penggunaan metode pembelajaran berbasis proyek dikatakan cocok untuk diterapkan mahasiswa apalagi pada saat pembelajaran daring. Oleh karena itu, dalam pembelajaran dengan menggunakan model pembelajaran berbasis proyek harus memperhatikan karakteristik dari model itu sendiri.

\section{KESIMPULAN}

Berdasarkan hasil penelitian yang telah dilakukan, dapat disimpulkan bahwa kemampuan berpikir tingkat tinggi mahasiswa dalam aspek critical thinking, creative thinking, decision making dan problem solving termasuk dalam kategori baik, dengan presentase critical thinking 69,24\%, creative thinking $71,42 \%$, decision making $58,24 \%$ dan problem solving $96,70 \%$. Aspek menunjukkan hasil yang paling berbeda dengan aspek kemampuan berpikir tingkat tinggi lainnya yaitu kategori baik dengan presentase 96, 70\%. Model pembelajaran berbasis proyek dalam pembelajaran IPA lanjut khususnya gelombang dan bunyi dapat mengembangkan kemampuan berpikir tingkat 
tinggi mahasiswa pada aspek critical thinking, creative thinking, decision making, dan problem solving. Untuk itu, peneliti merekomendasikan agar dosen atau guru dapat menerapkan model pembelajaran berbasis proyek dalam pembelajaran materi gelombang dan bunyi. Selain itu, agar pelaksanaan pembelajaran dengan model pembelajaran berbasis proyek dapat berjalan sesuai dengan tahap-tahapannya.

\section{DAFTAR PUSTAKA}

Ariyana, Y., Bestary, R., \& Mohandas, R. (2018). Buku pegangan pembelajaran berorientasi pada keterampilan berpikir tingkat tinggi. Direktorat Jenderal Guru dan Tenaga Kependidikan Kementerian Pendidikan dan Kebudayaan Hak.

Arizona, K., Abidin, Z., \& Rumansyah, R. (2020). Pembelajaran Online Berbasis Proyek Salah Satu Solusi Kegiatan Belajar Mengajar Di Tengah Pandemi Covid-19. Jurnal Ilmiah Profesi pendidikan, 5(1), 64-70.

Brookhart, S. M. (2010). How to assess higjer order thinking skills in your classroom. Alexandria, VA: ASCD .

Chasanah, ARU, Khoiri, N., \& Nuroso, H. (2016). Efektivitas Model Project Based Learning terhadap Keterampilan Proses Sains dan Kemampuan Berpikir Kreatif Siswa pada Pokok Bahasan Kalor Kelas X SMAN 1 Wonosegoro Tahun Pelajaran 2014/2015. Jurnal Penelitian Pembelajaran Fisika. 7 (1), 19-24.

Finita Dwi. (2015). Proyek Buku Digital: Upaya Peningkatan Keterampilan Abad 21 Calon Guru Sekolah Dasar Melalui Model Pembelajaran Berbasis Proyek. Metodik Didaktik Vol. 9, No. 2, Januari 2015.

Hutapea, J., \& Lubis, S. S. (2017). Desain Pembelajran Fisika: Mengembangkan Keterampilan Decision Making Menggunakan Model Project Based Learning.

Indriajati, R., \& Ngazizah, N. (2018). Pembelajaran Berbasis Proyek Terhadap Kreativitas dan Pemahaman Siswa SD Muhammadiyah Purworejo. DIALEKTIKA Jurnal Pemikiran dan Penelitian Pendidikan Dasar, 8(2), 111-117.

Insyasiska, D., Zubaidah, S., \& Susilo, H. (2017). Pengaruh Project Based Lerning terhadap Motivasi belajar, Kreativitas,Kemampuan Berpikir Kritis, dan Kemampuan Kognitif Siswa pada Pembelajaran Biologi. Jurnal Pendidikan Biologi, 2017,7.1:9-21.

Jumadin, L., Hidayat, A., \& Sutopo, S. (2017). Perlunya pembelajaran modelling instruction pada materi gelombang. Jurnal Pendidikan: Teori, Penelitian, dan Pengembangan, 2(3), 325-330.

Khotimah, K., \& Ngazizah, N. (2018). Pembelajaran Berbasis Proyek "Snake and Lad-Der" Untuk Meningkatkan Kreativitas Siswa Kelas V SD Muhammadiyah Purworejo Tahun Pelajaran 2018/2019. DIALEKTIKA Jurnal Pemikiran dan Penelitian Pendidikan Dasar, 8(2), 78-75.

Kusumaningrum, S., \& Djukri, D. (2016). Pengembangan perangkat pembelajaran model project based learning ( $\mathrm{PjBL}$ ) untuk meningkatkan keterampilan proses sains dan kreativitas. Jurnal Inovasi Pendidikan IPA, 2(2), 241-251. 
Linda, R. F. C., Widodo, S., Setyanto, S., Karimah, N., \& Ngazizah, N. (2019). Penerapan Project Based Learning Pada Praktikum Mahasiswa PGSD Semester 2 untuk Meningkatkan Kreativitas dan Pemecahan Masalah. Proceeding of The URECOL, 214-222.

Niswara, R., Muhajir, M., \& Untari, M.F.A. (2019). Pengaruh model project based learning terhadap hight order thinking skill. Mimbar PGSD Undiksha, 2019, 7.2.

Primayana, K. H. (2020). Menciptakan Pembelajaran Berbasis Pemecahan Masalah Dengan Berorientasi Pembentukan Karakter Untuk Mencapai Tujuan Higher Order Thingking Skilss (HOTS) Pada Anak Sekolah Dasar. Purwadita: Jurnal Agama dan Budaya, 3(2), 85-92.

Rahayu, H., Purwanto, J., \& Hasanah, D. (2017). Pengaruh Model Pembelajaran Project Based Learning (PjBL) Terhadap Kemampuan Berpikir Tingkat Tinggi Siswa. COMPTON: Jurnal Ilmiah Pendidikan Fisika, 4 (1).

Sugiyono. (2012). Metode Penelitian Pendidikan Pendekatan Kuantitatif, Kualitatif dan R \& D. Bandung: Alfabeta.

Wahyuningsih, Y., Rachmawati, I., Setiawan, A., \& Ngazizah, N. (2019). HOTS (High Order Thinking Skills) dan Kaitannya dengan Keterampilan Generik Sains dalam Pembelajaran IPA SD. Seminar Nasional Pendidikan dan Call for Papers (SNDIK) I 2019.

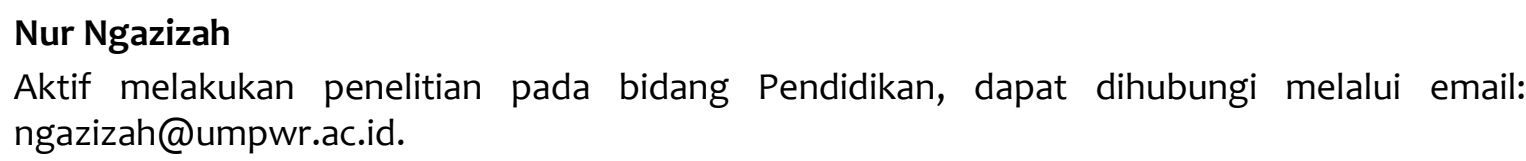

\section{Rizky Fadjar Choirrul Linda}

Aktif melakukan penelitian pada bidang Pendidikan, dapat dihubungi melalui email: rizkyfcl@gmail.com.

\section{Siska Giyan Kurniasari}

Aktif melakukan penelitian pada bidang Pendidikan, dapat dihubungi melalui email: sarisiska6599@gmail.com.

\section{Aulia Fakhrina}

Aktif melakukan penelitian pada bidang Pendidikan, dapat dihubungi melalui email: fakhrina.aulia27@gmail.com.

\section{Widanti}

Aktif melakukan penelitian pada bidang Pendidikan, dapat dihubungi melalui email: widanti1999@gmail.com. 